\title{
Hermit crabs (Crustacea: Anomura: Paguroidea) of the Dampier Archipelago, Western Australia
}

\author{
Patsy A. McLaughlin \\ Shannon Point Marine Center, Western Washington University, 1900 Shannon Point Road, \\ Anacortes WA $98221-9081 B$, U.S.A. \\ email: hermitifidalgonet
}

\begin{abstract}
The hermit crab fauna of the Dampier Archipelago of Western Australia was found to consist of 34 species, representing the two major paguroid families, Diogenidae with 24 and Paguridae with 10. The Archipelago has provided new distributional records for 9 of the 24 diogenid species: Clibanarius longitarsus, Dardanus hessi, D. squarrosus, Diogenes biramus, D. capricomis, D. dorotheae, D. pallescens, Paguristes alegrias and $P$. kimberlevensis. The presence of Ciliopagurus krempfi is a new record for Australia. Additionally, the new species of Paguristes, $P$. dampierensis, has been described in an accompanying paper in this volume. Of the 10 pagurid species, the Archipelago represents new distributional records for Paguritta harmsi, Pagurus compressipes and $P$. hedleyi. In addition to a new species, Pagurus sticticus, described from the Dampier collections, 4 species, Anapagurus bonnieri, Icelopagurus undulatus, Nematopagurus australis and N. ostlingochirus, represent new additions to the Australian fauna.
\end{abstract}

\section{INTRODUCTION}

The hermit crab fauna of central Western Australia has received only limited attention (e.g., Berry and Morgan, 1986); thus it was with genuine interest that the author accepted the invitation to identify the hermit crabs collected during the Woodside Dampier Expeditions of 1998-1999. The paguroids of the Dampier Archipelago have provided a very interesting mix of species common to the Indo-Pacific region, taxa thought to be endemic to Northem and Western Australia, some species known previously only from their type localities, some new to the Australian assemblage, and one heretofore apparently reported only as Pagurus sp. from the Kimberley region. This latter taxon is described herein and supplemental information gleaned from the Dampier material is provided for several additional species. Elements of these collections also have prompted two major taxonomic reviews (i.e., the present contribution and McLaughlin 2007, this volume).

\section{MATERIALS AND METHODS}

The hierarchical classification used follows that of Martin and Davis (2001); the division of the genus Paguristes Dana, 1851 is that of Rahayu (2005). The shield length (sl), as measured from the tip of the rostrum or midpoint of the rostral lobe (exclusive of the intercalary rostral process of Diogenes species) to the midpoint of the posterior margin of the shield provides an indication of animal size. The ratio of shield length to length of the ocular peduncle has been obtained by measuring the length of the left ultimate peduncular segment (cf. Powar, 1969), including the cornea, along the lateral surface; corneal diameter is the maximum measured width of the left cornea. The abbreviations stn, $\mathrm{n} \mathrm{mls}$, and ovig. refer to stn, nautical miles, and ovigerous, respectively.

In addition to the stations of the diving and dredging expeditions, the locations for which were provided by Hutchins and Berry (2004) and SlackSmith (2004), sampling was also conducted by staff from Museum Victoria in July 1999, in generally the same locations, but with different station numbers and slightly different geographical positions. Data for Museum Victoria stations at which hermit crabs were collected are given in Appendix 1.

In her initial report on the crustaceans collected during the Woodside Dampier Expeditions of 1998 and 1999, Hewitt (2004) listed visual sightings of six diogenid and one pagurid species collectively, made at 29 of the 70 stations surveyed during expeditions DA1 and DA3. Additionally, at 35 stations unidentified paguroids were collected and preserved for subsequent identification. During the dredging expedition, DA2, hermit crabs were collected at a total of 56 of the 100 stations sampled. In the present report, collection sites for the species examined and numbers of individuals are given by station number in Table 1. Four individuals, either juvenile or badly damaged, could not be identified 
Table 1 Summary of paguroid species by station and total number of specimens (NMV specimen number)

\begin{tabular}{|c|c|c|c|c|}
\hline Species & $\begin{array}{l}\text { Diving stations } \\
\text { (DA1, DA3) }\end{array}$ & $\begin{array}{l}\text { Dredge stations } \\
\text { (DA2) }\end{array}$ & $\begin{array}{l}\text { NMV stations } \\
\text { (DA2) }\end{array}$ & $\begin{array}{l}\text { Total number } \\
\text { of specimens }\end{array}$ \\
\hline Calcinus latens & $6,45,48$ & & & 6 \\
\hline Ciliopagurus krempfi & & 24 & & 1 \\
\hline Clibanarius longitarsus & 2,31 & & & 3 \\
\hline C. taeniatus & $2,9,38,54,58$ & & & 15 \\
\hline C. virescens & $\begin{array}{l}5,6,7,9,27 \\
38,45,48,51\end{array}$ & & & 31 \\
\hline Dardanus crassimanus & 3,47 & 77 & & 3 \\
\hline D. deformis & 45 & & & 1 \\
\hline D. hessii & & $22,23,53,55,82,86$ & & 7 \\
\hline D. imbricatus & & $\begin{array}{l}8,21,32,34,38,44 \\
51,52,55,56,57 \\
60,69,71,73,74 \\
82,85,88,91,92\end{array}$ & 18,73 & $28(3)$ \\
\hline D. lagopodes & 3,46 & & & 2 \\
\hline D. pedunculatus & $6,16,32,43$ & 90 & & 8 \\
\hline D. setifer & & $50,52,73,91$ & 6 & $5(1)$ \\
\hline D. squarrosus & 63 & $\begin{array}{l}59,62,65,72,73, \\
91,98\end{array}$ & & 11 \\
\hline Diogenes avarus & $\begin{array}{l}2,10,38,54,59 \\
62\end{array}$ & 26,73 & $\begin{array}{l}38,67,80,86, \\
92,93,94\end{array}$ & $21(6+)$ \\
\hline D. biramus & $31,38,49,68,70$ & & & 5 \\
\hline D. capricorneus & $38,51,54,62$ & 73,88 & & 7 \\
\hline$D$. dorotheae & 68 & $32,41,73$ & & 4 \\
\hline D. jousseaumei & & $\begin{array}{l}33,41,57,73,81 \\
82,88\end{array}$ & 80 & $13(1)$ \\
\hline D. pallescens & 37 & & & 2 \\
\hline D. rectimanus & & $\begin{array}{l}1,24,26,34,42,46 \\
62,78\end{array}$ & $\begin{array}{l}6,7,38,59 \\
67,80,92\end{array}$ & $10(4+)$ \\
\hline Paguristes alegrias & & $27,32,47$ & & 3 \\
\hline$P$. dampierensis & & $\begin{array}{l}23,24,25,26,52,54 \\
56,57,71,75,79\end{array}$ & 4 & $32(1)$ \\
\hline P. kimberleyensis & 56,65 & 73 & & 6 \\
\hline Pseudopaguristes monoporus & $\begin{array}{l}37,42,45,56,61 \\
65,70\end{array}$ & 73,76 & & 16 \\
\hline Anapagurus bonnieri & & $38,60,93$ & $\begin{array}{l}4,34,58,59 \\
66,68,73\end{array}$ & $3(21)$ \\
\hline Icelopagurus undulatus & & $31,70,71,73,89$ & 76 & $8(1)$ \\
\hline Nematopagurus australis & & $\begin{array}{l}25,26,31,51,57,69 \\
78,81,88\end{array}$ & 6,12 & $14(2)$ \\
\hline N. ostlingochirus & & $7,57,88$ & & 3 \\
\hline Paguritta harmsi & $32,47,66$ & & & 3 \\
\hline Pagurus boriaustraliensis & $37,45,70$ & 84 & & 6 \\
\hline P. compressipes & & 33,72 & & 3 \\
\hline P. hedleyi & $11,17,47,51,69$ & & & 5 \\
\hline$P$. sinuatus & 47 & & & 1 \\
\hline Pagurus sticticus sp. nov. & & $41,73,85$ & & 6 \\
\hline
\end{tabular}

and have been omitted from the report. The numbers and stations listed herein differ slightly from those given by Hewitt (2004: 179), because a few samples proved to contain only preserved gastropods or empty shells.

\section{RESULTS}

Thirty-four paguroid species, 24 diogenids and 10 pagurids, were identified from the Archipelago and include the following:

\section{Family Diogenidae Ortmann, 1892}

Calcinus latens (Randall, 1840)

Although widely distributed in Western Australia from the Kimberley's to Rottnest (Morgan, 1991), C. latens was represented in the Dampier Archipelago by only six moderately small specimens $(\mathrm{sl}=2.1-3.7$ $\mathrm{mm}$ ).

\section{Ciliopagurus krempfi (Forest, 1952)}

Davie (2002) listed Ciliopagurus strigatus (Herbst, 
1804) as the only species of the genus known from Australia. His report appears to have been based on Morgan's (1992) record from the Christmas and Cocos (Keeling) Islands, and Tudge's (1995) account of the species from Queensland. Morgan (1992) gave no supporting evidence for his identification; however, Tudge (1995: 30) described the dactyls of the second and third pereopods of the Queensland species as being uniformly orange. The solidly orange-coloured dactyls are one of the characters that distinguish $C$. krempfi from C. strigatus (cf. Forest, 1995). However, Tudge's (1995, pl. 4, fig. D) photo of the species shows the pereopodal dactyls as being banded red and white, the characteristic colour of C. strigatus. It is uncertain whether both C. strigatus and C. krempti occur in the Great Barrier Reef region or if Tudge's colour description was taken from a literature report of a species incorrectly identified; however, Forest (1995) reported $C$. strigatus from northeastern Australia. Morgan (1990) earlier had indicated that a single specimen collected from Rob Roy Reef in the Kimberley region agreed with the living colours described [accurately] by Haig and Ball (1988) for C. strigatus. The presence of C. krempfi in the Dampier Archipelago suggests that the species occurring in the Christmas and Cocos Islands may also be $C$. krempfi and not $C$. strigatus. Nonetheless, it is obvious that both species of Ciliopagurus are present in Australian waters.

\section{Clibanarius longitarsus (De Haan, 1849)}

Clibanarius longitarsus is broadly distributed throughout the Indo-Pacific (Rahayu and Forest, 1992). However, it had been reported in Western Australia only from the Christmas and Cocos Islands (Morgan, 1992). Its occurrence in Queensland was documented by Tudge (1995) and in the Northern Territory by Morgan (1987b). Its occurrence in the Dampier Archipelago is a new distributional record.

\section{Clibanarius taeniatus (H. Milne Edwards, 1848)}

Clibanarius taeniatus is a common shallow-water species in Western Australia. As reported by Morgan (1987b, 1992), C. taeniatus typically occupies a variety of gastropod shells. The small female $(\mathrm{sl}=1.4 \mathrm{~mm}$, WAM C 28028) from stn DA3/ 99/38 was found in an unusual habitat, a scaphapod shell. The animal's pleon was perfectly straight and the pleopods and uropods were held tightly against the body. However, the uropods were asymmetrical as seen in gastropod shell-dwelling individuals.

\section{Clibanarius virescens (Krauss, 1843)}

A common Indo-Pacific shallow water species with a broad distribution throughout Australia as well.

\section{Dardanus crassimanus (H. Milne Edwards, 1836) Figure la}

Dardanus crassimanus was first tentatively identified in Western Australia from three stations at Scott and Seringapatam Reefs (Berry and Morgan, 1986). Morgan (1989) and Jones and Morgan (1993) reported D. crassimanus from Rottnest in southwestern Western Australia, and the former author discussed the potential confusion of this species with $D$. setifer (H. Milne Edwards, 1836) that had been reported from the Northern Territory by Morgan (1987b). Both species have been recognized in the Dampier collections. Dardanus crassimanus was collected at diving stations DA1/98/03 and DA3/ $99 / 47$ in depths of $0-4 \mathrm{~m}$, and at trawling station DA2/99/77 in 13-14 m. Although the two species are generally very similar in overall appearance, they are distinguishable by the sculpturing of the lateral faces of the dactyl and propodus of the left third pereopod. This propodal surface in $D$. crassimanus (Figure 1a) has a moderately broad, elevated tuberculate and often spinulose ridge separated from the tessellated dorsal margin by a wide, deep sulcus and from the similarly cut ventral margin by a much narrower sulcus. The surface of the dactyl is marked by a broad and deep sulcus in the dorsal half and a tuberculate ridge in the ventral half that is contiguous with or only weakly separated from the tessellated ventral margin.

\section{Dardanus deformis (H. Milne Edwards, 1836)}

Morgan (1990) cited, without comment, H. Milne Edwards' (1836) illustration of Dardanus deformis as plate 13, figure 4, whereas both Alcock (1905) and Lewinsohn (1969) had given it as plate 14, figure 2 . The latter pagination was also provided by Davie (2002: 48). The error was actually that of the original author. The figure caption accompanying the species' description (H. Milne Edwards, 1836: 272 ) is for plate 14, figure 2; however, the illustration of the species appears on plate 13, figure 4. Plate 14, figure 2 is a frontal view of Diogenes merguiensis De Man, 1888, that H. Milne Edwards (1836) had incorrectly interpreted to be Diogenes miles (Fabricius, 1787) (cf. McLaughlin and Holthuis, 2000: 257).

\section{Dardanus hessii (Miers, 1884)}

Forest and Morgan (1991) reported D. hessii from North West Cape and Point Cloates in Western Australia and New Year Island in northern Australia. Its presence in the Dampier Archipelago is a new distributional record. 


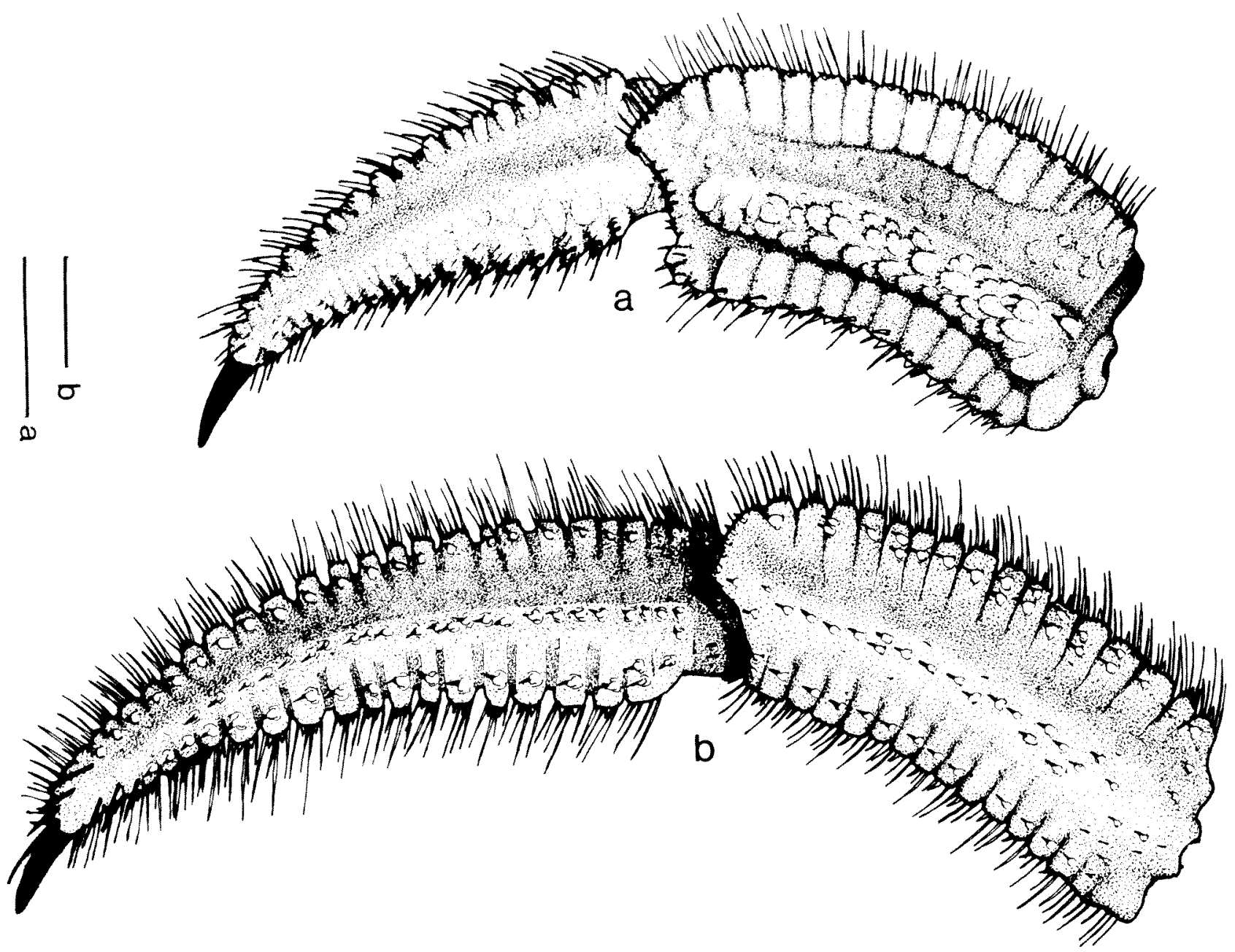

Figure 1 Dactyl and propodus of left third pereopod (lateral view). a, Dardanus crassimanus (H. Milne Edwards, 1836), ovig. female ( $\mathrm{sI}=8.1 \mathrm{~mm}$ ), WAM C 29570; b, Dardanus setifer (H. Milne Edwards, 1836), ovig. female $(\mathrm{sl}=6.5 \mathrm{~mm}$ ), WAM C 25946. Scales equal $2 \mathrm{~mm}$ (a) and $1 \mathrm{~mm}$ (b).

\section{Dardanus imbricatus (H. Milne Edwards, 1848)}

Cook (1989) divided $D$. imbricatus sensu lato into four distinct species and designated a neotype from Casuarina Beach, Northern Territory for $D$. imbricatus sensu stricto. That species is broadly distributed from Sharks Bay, Western Australia to Moreton Bay, Queensland (Cook, 1989), and is the most abundant species of Dardanus found in the Dampier Archipelago.

\section{Dardanus lagopodes (Forskål, 1775)}

Among the diogenid species visually identified during the diving expeditions was Dardanus megistos (Herbst, 1804) from five stations (Hewitt, 2004: 179). Only at station 46 was the field identification more than a visual record. However, at three of the five visual stations, specimens also were collected and in no instance was D. megistos among the species of Dardanus represented. The species from visual report station 46 proved to be D. lagopodes. This latter species was visually identified in the field tentatively at station 57; however, the only specimen of Dardanus preserved from station 57 was $D$. imbricatus.

Not only is $D$. lagopodes known from Queensland, the Northern Territory and the Kimberley region of Western Australia, as well as the Christmas and Cocos (Keeling) Islands, it has been reported from Scott and Seringapatam Reefs by Berry and Morgan (1986) as Dardanus sanguinolentus (Quoy and Gaimard, 1824).

\section{Dardanus pedunculatus (Herbst, 1804)}

The tentative visual record of $D$. pedunculatus at station DA3/99/43 (Hewitt, 2004: 179) has been confirmed by the presence, in the collection, of a large female $(\mathrm{sl}=10.8 \mathrm{~mm})$, WAM C 27974 from that station.

\section{Dardanus setifer (H. Milne Edwards, 1836) Figure 1b}

Morgan (1987b) reported $D$. setifer from the Northern Territory, but noted that because of the 
identity confusion with D. crassimanus, its distribution was uncertain. As noted previously, both $D$. crassimanus and the specie's herein interpreted as D. setifer occur in the Dampier Archipelago. As may be seen in Figure 1b, when cleaned of debris, the lateral face of the propodus of the left third pereopod of the Dampier D. setifer has a distinct median row of small, tuberculate, corneous-tipped spines on a slightly elevated ridge; the dorsal and ventral marginal tessellations each are armed with one or two small, corneous-tipped spines. The dactyl has a similar median row of corneous-tipped spines, not as distinctly delimited from the ventral row of "scutes". Although three longitudinal crests on these surfaces were described by $H$. Milne Edwards (1836) in his original description of $D$. setifer, the median row is not apparent in the illustration of this appendage by Fize and Serene (1955, fig. 28C). The outer face of the illustrated left chela, however does have the rosette of short setae encircling each spine that is also characteristic of D. setifer (cf. Morgan, 1989, fig. 3c)

\section{Dardanus squarrosus Cook, 1989}

Because the paratype of $D$. squarrosus lacked locality data, Cook (1989) listed the distribution of this species only as Cape Jaubert. Its presence in the Dampier Archipelago represents an additional locality for the distribution of this species in Western Australia, where it is found sympatrically with D. imbricatus. In addition to the characters cited by Cook (1989) to differentiate between the two species, even in preservative when colour is present, they are immediately separable. Living colour was reported by Haig and Ball (1988) for $D$. imbricatus and included the notation that the dactyls of the second and third pereopods were reddish brown, whereas the other segments were white. The dactyls of this species, even after several years in preservative, retain the red colouration in stark contrast to the white of the other segments. On the contrary, in preservative the dactyls of the second and third pereopods of D. squarrosus are mottled red and white, with the red colouration on the lateral face of the left third restricted to the scutes. The propodi, carpi and meri also have red mottlings on white backgrounds, with a concentration of colour forming an irregular median band, particularly on each propodus.

\section{Diogenes avarus Heller, 1865}

Diogenes avarus was the most common hermit crab collected during the expeditions; however, the exact number is not apparent in Table 1. Three mixed samples from the Museum Victoria collections contained numerous small and badly damaged specimens. Of the detached chelipeds present, some were tentatively identifiable as $D$. avarus, and while the stations numbers given in Table 1 indicate the species' presence, no specimen count was possible.

\section{Diogenes biramus Morgan, 1987}

In his original description of $D$. biramus, Morgan (1987b) distinguished his new species from the other members of the group of Diogenes species characterized by having antennal peduncles shorter than the ocular peduncles, by the presence in males of biramous pleopods. His type series consisted of just two specimens. When additional specimens were collected in the Kimberley region, that had only rudimentary or vestigial second rami, Morgan (1990) amended the diagnosis of D. biramus, but still considered the extremely long ocular peduncles a differentiating character. Tudge (1995) extended the range of this species to the Great Barrier Reef. Five specimens, agreeing with Morgan's (1987b) description of $D$. biramus were identified among the Dampier collections, representing a further range extension.

\section{Diogenes capricorneus Grant and McCulloch,} 1906

Davie (2002) indicated that the only published record of $D$. capricorneus was from the type locality of Masthead Island, Queensland. However, seven specimens, seemingly identifiable as Grant and McCulloch's (1906) species were found during the Dampier surveys. As noted by Morgan (1987b, 1990) and Haig and Ball (1988), D. capricorneus also is one of that group of species characterized by exceptionally long ocular peduncles. However, as was demonstrated by McLaughlin (2002a), ocular peduncle length is commonly growth related, with length increasing with increased animal size. The specimens considered to represent $D$. capricorneus are differentiated from $D$. biramus by the armature of the left chela, which consists of a prominent row of spines in the midline of the outer face of the left palm and a smaller additional row between that row and the row of spines on the upper margin in the former species. Nonetheless, until the type materials of both species are reviewed and a sufficient number of specimens examined to assess variation, the possibility of conspecificity cannot be discounted.

\section{Diogenes dorotheae Morgan and Forest, 1991}

The recognition of $D$. dorotheae in the Dampier Archipelago is the first record of this species since its original description, based on a single specimen, from west of Cape Bossut. 
Diogenes jousseaumei (Bouvier, 1897)

Specimens identifiable morphologically as both D. setocristatus Morgan and Forest, 1991, and D. stenops Morgan and Forest, 1991, were represented in the Dampier collections. However, the fact that all specimens shared the same colour pattern of the ocular peduncles prompted McLaughlin (2005) to review not only those two species, but the entire "Troglopagurus group" of Diogenes. The results of that investigation showed that both $D$. setocristatus and $D$. stenops were junior subjective synonyms of D. jousseaumei.

\section{Diogenes pallescens Whitelegge, 1897}

Although Whitelegge's (1897) species has not been reported from Western Australia, Morgan (1987b, 1990) reported both D. gardineri Alcock, 1905, and D. serenei Forest, 1956, from the Northern Territory and northwest Western Australia. McLaughlin (2002a) placed both species in synonymy with $D$. pallescens. Its presence in the Dampier Archipelago represents an additional distributional record. Tudge (1995) recorded $D$. pallescens, $D$. gardineri and $D$. serenei from the Great Barrier Reef.

\section{Diogenes rectimanus Miers, 1884}

Diogenes rectimanus is also a common constituent of the Dampier fauna, whose numbers are not accurately reflected in Table 1 . Like $D$. avarus, $D$. rectimanus was present in the Museum Victoria collections in three mixed lots, but could only be recognized by disarticulated left chelipeds, thus accurate tabulations of species occurrences could not be made.

\section{Paguristes alegrias Morgan, 1987}

Davie (2002) gave the distribution of this species as Northern Territory and northwest Western Australia, although the only published report of it is Morgan's (1987a) original description from Coral Bay, Port Essington, Northern Territory. It would appear that the presence of $P$. alegrias in the Dampier Archipelago is a major range extension.

\section{Paguristes dampierensis McLaughlin, 2007}

The recognition of this species, which very closely resembles $P$. brevirostris Baker, 1905, is described as a new species in the major review of Australian species of the genera Paguristes, Stratiotes, and Pseudopaguristes appearing in this volume (McLaughlin, 2007).

Paguristes kimberleyensis Morgan and Forest, 1991 Specimens of $P$. kimberleyensis collected during the Dampier expeditions represented not only a major range extension for the species, but made a substantive redescription of the species possible (Mclaughlin, 2007, this volume).

\section{Pseudopaguristes monoporus (Morgan, 1987)}

When Rahayu (2005) found that this distinctive Australian species had only eight pairs of functional gills, she transferred it to Pseudopaguristes McLaughlin, 2002. It also has recently been reported from Indonesia and Guam.

\section{Family Paguridae Latreille, 1802}

\section{Anapagurus bonnieri Nobili, 1905}

Haig and Ball (1988) recorded several specimens from Pulau Saparua, Indonesia that they identified only as Anapagurus sp. García-Gómez (1994) reexamined those specimens and found them to represent $A$. bonnieri. The species previously had been known only from the Red Sea and Persian Gulf. The presence of $A$. bonnieri in the Dampier Archipelago represents an additional range extension and a new addition to the Australian fauna.

\section{Icelopagurus undulatus McLaughlin, 2006}

This recently described species (McLaughlin, 2006a) is reported for the first time outside the environs of New Caledonia and is a new addition to the Australian hermit crab faunal assemblage.

\section{Nematopagurus australis (Henderson, 1888)}

Davie (2002) listed only Nematopagurus muricatus as an Australian representative of the genus. However, Davie's record was based on the tentative identification made by Morgan (1992) of a small male from Cocos (Keeling) Islands. McLaughlin (2004) determined that Morgan's (1992) specimen actually represented $N$. gardineri Alcock, 1905. Nematopagurus gardineri has not been found in the Dampier Archipelago, but both N. muricatus sensu Wang (1983: 54) and Rahayu (1996: 350) and N. gardineri of Haig and Ball (1988: 185) were found by McLaughlin (2004) to be synonymous with $N$. australis.

Despite its epithet, the Dampier specimens represent the first record of Nematopagurus australis in Australian waters. It was described by Henderson (1888) from the Arafura Sea and Fiji and has since been reported from the South China Sea, Malaysia and New Caledonia (McLaughlin and Wang, 2002; McLaughlin, 2004).

The Dampier specimens of $N$. australis exhibit variations in the armature of the chelae not seen in specimens from other locales. Rather than the single 
row of small spines on the dorsomesial margin of the dactyl of the right chela, for example, frequently a double row of subacute spines or even blunt tubercles is present. Similarly, the marginal spines on the palm and fixed finger tend to be larger and often tuberculate. The median row of spines on the palm may be replaced by a double or triple row of tubercles or subacute spines and the spines of the dorsal surface frequently are simple tubercles. The dorsomesial row of spines on the left palm is often extremely prominent, particularly in females, and the median row is commonly represented by a slightly elevated double or triple row of tuberculate spines or tubercles. However, despite these variations, there is sufficient agreement in all pertinent diagnostic characters to preclude separation of the Dampier population as a distinct taxon. McLaughlin (2004: 204) noted comparable variability in Western Australian specimens of Nematopagurus spinulosensoris McLaughlin and Brock, 1974.

\section{Nematopagurus ostlingochirus McLaughlin, 1997} Figure 2

Although also recently found in Taiwan (McLaughlin, personal observation), this is the first published report of this species since its original description based on a small and incomplete specimen from the Tanimbar Islands of Indonesia. In addition to a major range extension for the species, as well as a new addition to the Australian fauna, the Dampier specimens have permitted a more complete description, including information on variation.

\section{Material examined}

Western Australia, Dampier Archipelago. WAM C 25970, (1 male, sl = $1.7 \mathrm{~mm})$, stn DA2/99/07, 12 $\mathrm{km} \mathrm{E}$ of $20^{\circ} 20.90^{\prime} \mathrm{S}, 116^{\circ} 57.04^{\prime} \mathrm{E}, 37 \mathrm{~m}, 15 / 07 / 1999$; WAM C 25954 (1 male, sl $=2.7 \mathrm{~mm}$ ), stn DA2/99/57, $1.9 \mathrm{~km}$ N of Roly Rock $\left(20^{\circ} 29.03^{\prime} \mathrm{S}, 116^{\circ} 30.45^{\prime} \mathrm{E}\right), 32-$ $33 \mathrm{~m}, 21 / 07 / 1999$; WAM C 26035, (1 ovig. female, sl $=2.5 \mathrm{~mm}), \operatorname{stn} \mathrm{DA} 2 / 99 / 88,1.3 \mathrm{~km} \mathrm{~N}$ point of $W$ of Brigadier 1. $\left(20^{\circ} 26.04^{\prime} \mathrm{S}, 116^{\circ} 36.77^{\prime} \mathrm{E}\right), 33.5-38.5 \mathrm{~m}$, 26/07/1999.

\section{Amended description}

Shield (Figure 2a) longer than broad to nearly as broad as long; truncate posterior margin with median concavity; dorsal surface with very sparse setae. Rostrum broadly rounded, not overreaching lateral projections. Lateral projections prominent, roundly subquadrate, each with small submarginal spine laterally. Ocular peduncles moderately short, 0.7-0.9 length of shield; dorsal surfaces each with median tuft of stiff setae at base of cornea, occasionally 1 additional tuft on dorsal surface; corneal diameter 0.5-0.6 of peduncular length. Ocular acicles small, projecting portion triangular to subrectangular, terminating acutely or subacutely, each with concave dorsal surface and prominent simple submarginal spine. Antennular peduncles overreaching distal margin of corneas by 0.1-0.2 length of ultimate segments; basal segment with small spine dorsolaterally. Antennal peduncles reaching beyond bases but not overreaching distal margins of corneas; second segment with dorsolateral distal angle produced, terminating in prominent spine, lateral margin sometimes with accessory spine; dorsomesial distal angle with small spine. Antennal acicle reaching proximal half of ultimate peduncular segment; terminating in acute spine; mesial margin with row moderately long stiff setae. Antennal flagella with 1 or 2 very short setae every 1 or 2 articles and occasionally 1 long seta.

Chelipeds subequal; right (Figure 2b) slightly longer and stronger. Dactyl slightly shorter than to equalling length of palm; cutting edge with 2-5 calcareous teeth, terminating in small corneous claw and slightly overlapped by fixed finger; dorsal surface with few spines or spinules proximally, becoming median row of spines not extending to tip in larger specimens and several moderately short, sometimes distally curved or curled setae, longer simple setae distally, dorsomesial margin with row of spinules or small spines at least in proximal half; mesial and ventral surfaces with scattered longer setae. Palm slightly longer than carpus; dorsomesial margin with row of moderately small to small spines; dorsal midline with longitudinal row of spines extending to distal half of fixed finger, dorsal surface with scattered spinules, particularly near junction of fixed finger with dactyl and moderately short, straight or curled setae, longer setae marginally; dorsolateral margin with row of spines extending approximately half length of fixed finger; dorsal surface of fixed finger with similarly straight, curved or curled setae proximally and scattered longer setae distally; cutting edge with 2 large calcareous teeth proximally, 1 large and several small calcareous teeth distally, terminating in small corneous claw; lateral and ventral surfaces of palm and fixed finger with scattered setae. Carpus with 1-4 small spines on dorsodistal margin, dorsomesial margin with row of spines; dorsal surface with scattered moderately long stiff setae and row of smaller spines approximating dorsolateral margin; lateral and mesial faces with few short transverse rows of stiff setae. Merus subtriangular; dorsodistal margin with row of stiff setae; dorsal margin and mesial and lateral faces with few long stiff setae; ventrolateral margin with 2 or 3 small spines distally; ventromesial margin with 2 to several slightly stronger spines in distal half.

Left cheliped reaching almost to tip of dactyl of 


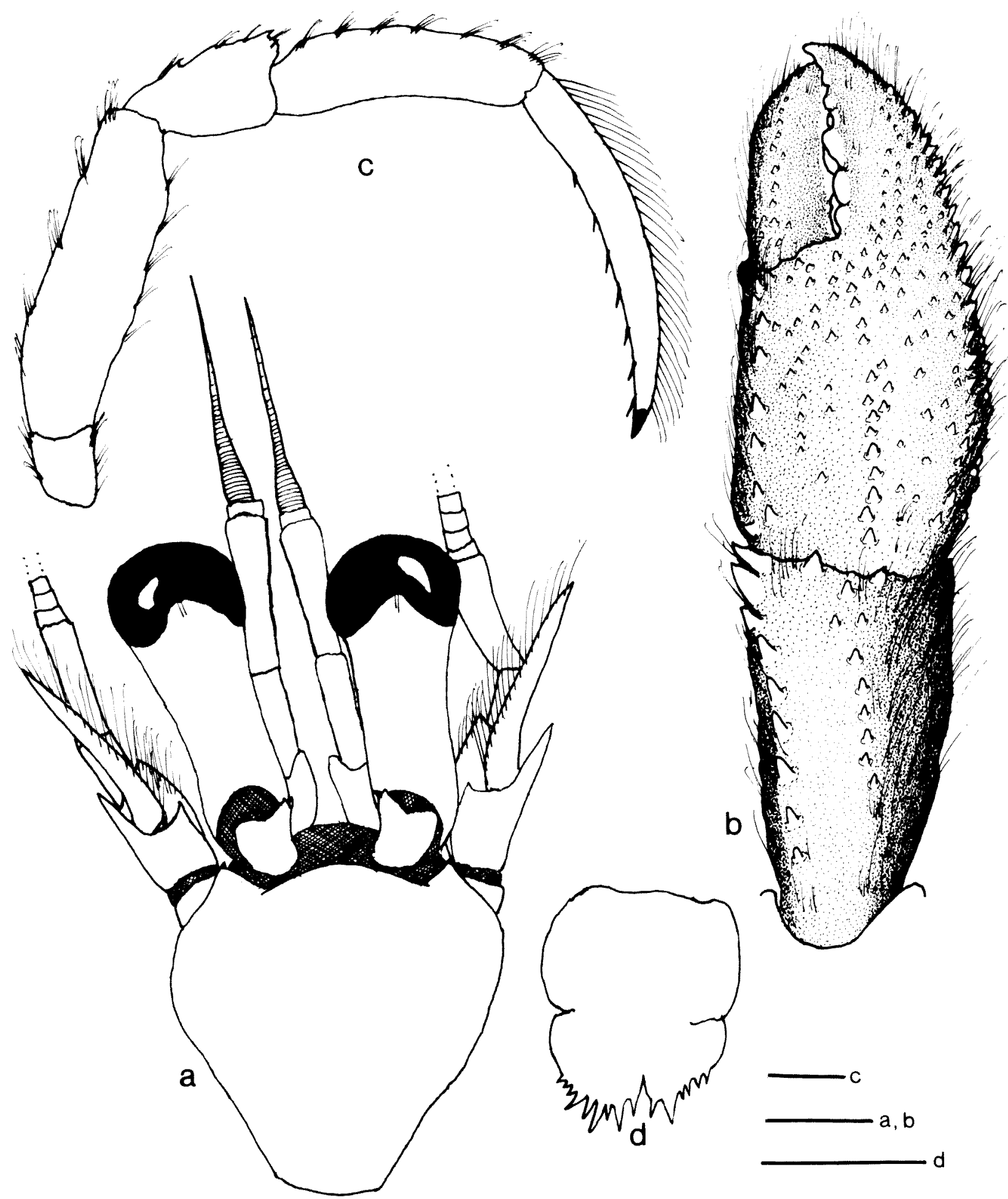

Figure 2 Nematopagurus ostlingochirus McLaughlin, 1997, male ( $\mathrm{sl}=2.7 \mathrm{~mm}$ ), WAM C 25954. a, shield and cephalic appendages (aesthetascs omitted); $\mathbf{b}$, chela and carpus of right cheliped (dorsal view); $\mathbf{c}$, right second pereopod (lateral view); $d$, telson (dorsal view). Scales equal $1 \mathrm{~mm}$.

right; moderately slender. Dactyl slightly shorter to considerably longer than palm; cutting edge with row of small corneous teeth, terminating in small corneous claw and slightly overlapped by fixed finger; dorsal surface with few to several small spines and few short setae in proximal half, becoming well defined row of spines distally in larger specimens, and with longer setae marginally; mesial and ventral surfaces with few moderately long setae. Palm with somewhat irregular row of spines on dorsomesial margin; dorsal surface with longitudinal row of small spines in slightly raised midline, extending half length of fixed finger and partially obscured by short setae; dorsolateral 
margin with row of spines, extending to distal half of fixed finger and numerous longer setae; cutting edge of fixed finger with row of small calcareous teeth. Carpus slightly longer than merus; dorsodistal margin with 1 small spine; dorsomesial and dorsolateral margins each with row of spines strongest mesially; mesial, lateral and ventral surfaces with numerous, long stiff setae; ventrolateral distal angle with small spine. Merus with few stiff setae dorsal surface, particularly at distal margin; ventromesial and ventrolateral margins each with 1 or 2 strong spines in distal halt.

Second (Figure 2c) and third pereopods overreaching outstretched chelipeds. Dactyls $1.2-$ 1.4 length of propodi; dorsal surfaces varying from row of long regularly-spaced stiff setae on right second to appreciably more irregular and sparser on left third; mesial faces each with row of small corneous spines dorsally; lateral faces with few scattered setae; ventral margins each with row of 512 corneous spines. Propodi somewhat longer than carpi; surfaces each with few setae; 1 or 2 small corneous spinules at ventrodistal angle. Carpi 0.50.6 length of meri; dorsal surfaces of second pereopods each with dorsodistal spine and 1 or 2 spines in proximal 0.5 , third pereopods each with only small dorsodistal spine; ventral surfaces with few setae. Meri with few setae dorsally and ventrally; ventral margins of second pereopods each also with few small spinules distally. Fourth pereopods each with small preungual process at base of claw. Anterior lobe of sternite of third pereopods narrowly to moderately broadly subsemicircular, with few marginal setae.

Male with long right sexual tube, left tube stout, moderately short, directed toward right coxa. Telson (Figure $2 \mathrm{~d}$ ) with posterior lobes practically symmetrical, nearly subquadrate to slightly rounded, separated by moderately deep median cleft; terminal margins straight, both with 3 or 4 large spines, left with additional smaller spines; lateral margins rounded, each with distinct chitinous plate, denticulate in larger female.

\section{Remarks}

McLaughlin (1997) considered $N$. ostlingochirus most closely allied to $N$. indicus Alcock, 1905 and N. gardineri Alcock, 1905; however, her evaluation was based primarily on shared character of a median row of spines on the dorsal surface of each chela. She distinguished the Tanimbar specimen by the presence of curled and curved setae. In a more in depth study of the species of Nematopagurus, McLaughlin (2004) found that the median row of spines was a character shared by several species, and setation was an extremely variable attribute. Although acknowledging the possibility that $N$. ostlingochirus might prove to be simply a variant of another species in the genus, McLaughlin retained it as a distinct taxon until such time as additional material was found. The three specimens in the Dampier collection share with the holotype of $\mathrm{N}$. astlingochirus the cluster of spines on the proximal dorsal surface of the dactyls of the chelipeds, albeit also developing a definitive row of spines that are continued distally. All three Dampier specimens are larger than the holotype, but the smallest has a much shorter spine-row, suggesting the development of these spines is growth related. Similarly, the pereopodal dactyls exhibit variations that suggest characters such as dactylar length, the number of comeous spines on ventral margins, and the density of the setae on the dorsal margins are also influenced by growth. Only the third pereopod is present in the holotype (male, $\mathrm{sl}=1.2 \mathrm{~mm}$ ), and it has a short dactyl with five ventral comeous spines and sparse setae on the dorsal surface. The smallest Dampier specimen (male, $\mathrm{sl}=1.4 \mathrm{~mm}$ ) has moderately short pereopodal dactyls, each with six or seven corneous spines, and the setation on the dorsal surfaces varies from regular rows of moderately long, stiff setae on the second pereopods and right third, to more numerous, but not regularly set or as stiff on the left third. The large Dampier female has much longer dactyls, more numerous corneous spines, and greater dactylar setation; however, there is still a difference between the left third and other dactyls. Nematopagurus ostlingochirus is readily distinguished from $N$. australis, the other species of the genus found in the Dampier Archipelago, by the presence of a row of very obvious spines on ventral margin of each pereopodal dactyl. The pereopodal dactyls of $N$. australis each has a row of quite small spines displaced to the mesioventral margin, thus usually not apparent when the dactyls are viewed laterally. The median row of spines on the dorsal surface of the dactyl of each cheliped of $N$. ostlingochirus is also diagnostic, but in the Dampier specimens of $N$. australis, the dactyls of the chelipeds usually are each armed with a double dorsomesial row of spines, thus potentially misleading. Nematopagurus ostlingochirus is also quite similar to $N$. gardineri, reported from the Cocos (Keeling) Islands by Morgan (1992) as Nematopagurus of. muricatus (Henderson, 1896). However, the two species may be differentiated by the presence, in $N$. gardineri, of a row of stiff setae on the dorsal surface of each pereopodal dactyl that is interspersed with corneous spines. These comeous spines are not present in $N$. ostlingochirus.

\section{Paguritta harmsi (Gordon, 1935)}

Paguritta harmsi was reported as occurring uncommonly at Christmas Island by Morgan (1992). 
Paguritta sp. was recorded from visual observations at five diving stations; however, $P$. harmsi was collected at only one of the stations of visual sightings and two additional stations. Although not particularly common, its distribution now includes the mainland of Western Australia for the first time.

\section{Pagurus boriaustraliensis Morgan, 1990}

Pagurus boriaustraliensis was previously reported only from the Northern Territory and the Kimberly region of northern Western Australia. Its presence in the Dampier Archipelago represents a southern extension of range.

\section{Pagurus compressipes (Miers, 1884)}

The Australian distribution of this species was reported by Davie (2002) as a limited range in northern Queensland. Pagurus compressipes was also reported from the Arafura Sea by McLaughlin (1997) on the basis of a specimen misidentified as Pseudopagurodes piliferus (Henderson, 1888) by Henderson (1888) (as Pagurodes piliferus). The occurrence of Pagurus compressipes in the Dampier Archipelago reflects a major range extension.

\section{Pagurus hedleyi (Grant and McCulloch, 1906)}

Morgan (1987b, 1990) reported this species from the Northern Territory and Kimberley regions as Pagurus kulkarnii Sankolli, 1962. After examining the type of $P$. hedleyi and several specimens of the true P. kulkarnii, McLaughlin (2002b) concluded that the colour patterns described by Morgan $(1987 \mathrm{~b}, 1990)$ agreed with those of $P$. hedleyi rather than P. kulkarnii and put Morgan's northern Australian specimens into synonymy with $P$. hedleyi. The occurrence of $P$. hedleyi in the Dampier Archipelago represents a further western distribution of this species. Because of the potential for confusion not only with $P$. kulkarnii, but also with the new species described below, a diagnosis of $P$. hedleyi is given.

\section{Diagnosis}

Shield approximately as broad as long. Rostrum short, broad, produced little if at all beyond level of lateral projections. Ocular peduncles moderately long, but shorter than antennular and antennal peduncles; corneas not dilated; ocular acicles small, terminating in slender spine. Antennal acicles reaching to distal margins of corneas.

Chelipeds with setation varying from moderate to sufficiently dense to conceal armature. Right cheliped with slender hiatus between dactyl and fixed finger; dactyl with 1 or 2 irregular, longitudinal rows of prominent spines or spiniform tubercles on dorsomesial margin and dorsal surface; palm with row of small spines on both dorsomesial and dorsolateral margins, dorsal surface with scattered small spines; carpus with spinulose dorsal surface, distal margin with row of small spines, ventromesial margin very strongly produced into outwardly-directed crest-like lobe, but only weakly developed in specimens with shield lengths $<3.0$ $\mathrm{mm}$; merus with similar development of ventromesial lobe. Left cheliped with prominent hiatus between dactyl and fixed finger; dactyl with dorsomesial row of spines; palm with row of small spines on both dorsomesial and dorsolateral margins, surface somewhat flattened and with few scattered spines or spinules; carpus with row of prominent, widely-spaced spines on ventromesial margin, dorsal surface with few scattered spines. Ambulatory legs with dactyls slightly shorter than propodi, ventral margins each with row of 5-7 corneous spinules; propodi each with row of corneous spinules on ventral margins; carpi each with small dorsodistal spine. Telson with posterior lobes separated by distinct median cleft; terminal margins each with row of irregularly-sized usually subacute spines.

\section{Colour}

Ocular peduncles white with broad subproximal orange band; cornea black with white speckles. Antennules bluish; penultimate segment of peduncle with broad orange band distally. Chelipeds turquoise with brown spots or short stripes; setae white. Ambulatory legs turquoise with interrupted brown stripes (after Haig and Ball, 1988)

\section{Habitat}

In the Dampier Archipelago, associated with sandy and muddy flats with igneous boulders.

\section{Distribution}

Arafura Sea, Indonesia; Port Curtis, Queensland, Northern Territory, Western Australia; intertidal to $66 \mathrm{~m}$.

\section{Pagurus sticticus sp. nov. Figure 3}

?Pagurus spec. - Morgan, 1990: 27.

\section{Holotype}

Western Australia, Dampier Archipelago. WAM C 25997 (male, sl = $2.7 \mathrm{~mm}$ ), stn DA2/99/41, $1.3 \mathrm{n}$ $\mathrm{mls} \mathrm{N}$ of Rocky Head, Enderby I. $\left(20^{\circ} 35.63^{\prime} \mathrm{S}\right.$, $116^{\circ} 28.07^{\prime} \mathrm{E}$ to $\left.20^{\circ} 35.09^{\prime} \mathrm{S}, 116^{\circ} 27.81^{\prime} \mathrm{E}\right), 16.0-17.4 \mathrm{~m}$, 20/07/1999.

\section{Paratypes}

Western Australia, Dampier Archipelago. WAM 


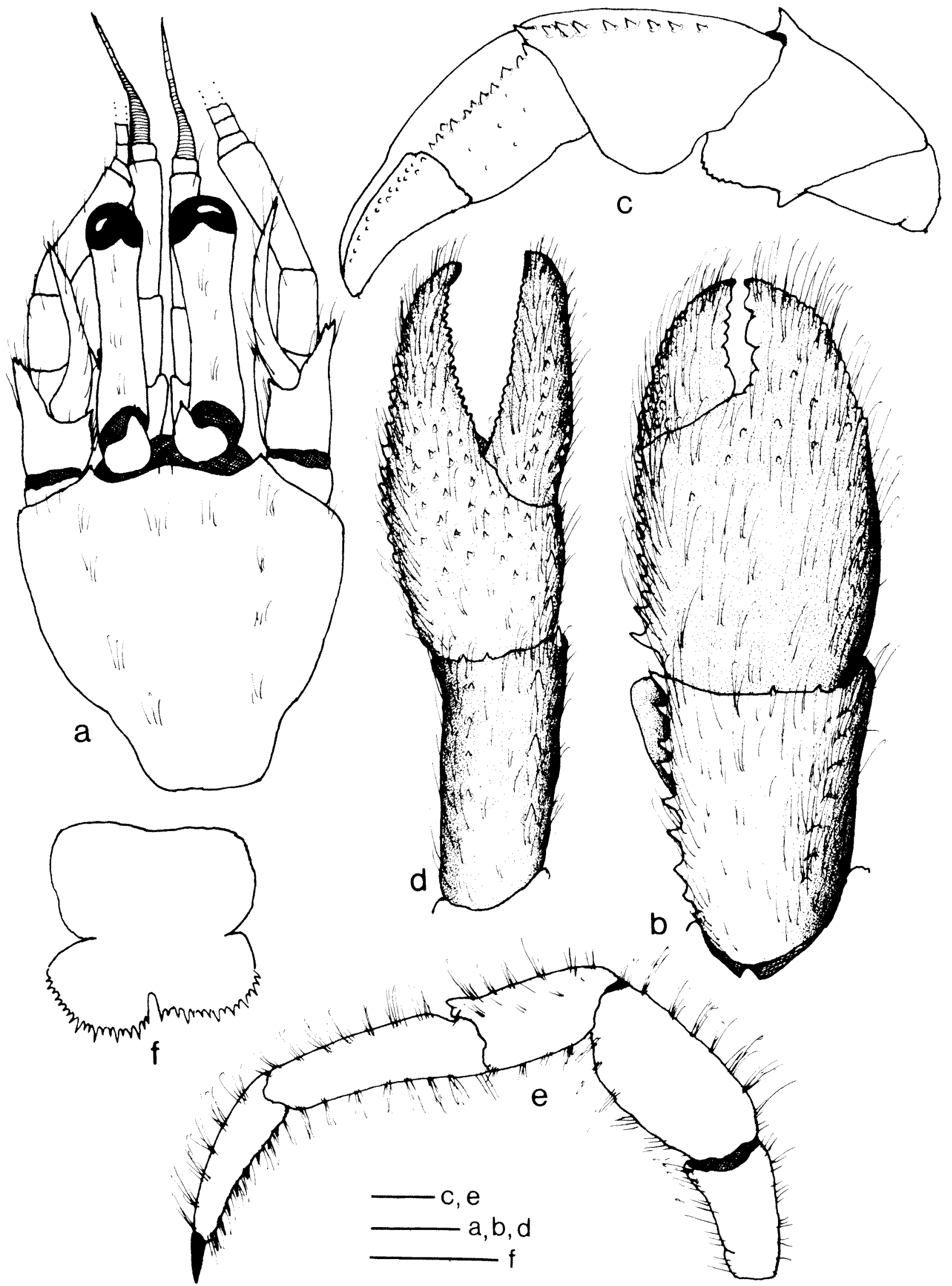

Figure 3 Pagurus sticticus sp. nov., male holotype ( $\mathrm{sl}=2.7 \mathrm{~mm})$, WAM C 25997. a, shield and cephalic appendages (aesthetascs omitted). b, chela and carpus of right cheliped (dorsal view); $\mathbf{c}$, right cheliped (mesial view; setae omitted); $d$, chela and carpus of left cheliped (dorsal view); e left third pereopod (lateral view); $f$, telson (dorsal view). Scales equal $1 \mathrm{~mm}$. 
C 29569 (1 juv. female, $s \mathrm{l}=1.4 \mathrm{~mm}$ ), stn DA2/99/73, $3.25 \mathrm{n} \mathrm{ml} \mathrm{S}$ of Rocky Head, Enderby 1., $12.5 \mathrm{~m}, 24$ / 07/1999; WAM C 25924 ( 1 female, $\mathrm{sl}=1.7 \mathrm{~mm}$ ), WAM C 25960 (3 ovig. females 1.6-2.7 mm) and WAM C 26033 (1 female, $\mathrm{sl}=2.4 \mathrm{~mm}$ ), stn DA2/99/ 85 , $-2.6 \mathrm{n} \mathrm{mls} \mathrm{E}$ of $\mathrm{E}$ point of Brigadier $\mathrm{I}$. $\left(20^{\circ} 26.38^{\prime} \mathrm{S}, 116^{\circ} 39.76^{\prime} \mathrm{E}\right.$ to $\left.20^{\circ} 26.09^{\prime} \mathrm{S}, 116^{\circ} 40.10^{\prime} \mathrm{E}\right)$, 28-29 m, 26/07/1999.

\section{Description}

Shield (Figure $3 a$ ) varying from longer than broad to approximately as broad as long, with scattered sparse tufts of thick setae. Rostrum broadly rounded, not usually produced beyond level of lateral projections. Anterior margin between rostrum and lateral projections somewhat concave; anterolateral margins sloping or terraced; posterior margin truncate.

Ocular peduncles varying from $0.3-0.9$ length of shield with increasing animal size, each with row of sparse tufts of thick setae; corneas $0.1-0.2$ of peduncular length, decreasing in size with increased growth. Ocular acicles moderately large, projecting portion roundly triangular; with moderately prominent submarginal spine; interocular lobe distinct.

Antennular peduncles reaching beyond distal margins of corneas by $0.2-0.8$ length of ultimate segment. Dorsodistal margin of ultimate segment with 1 long simple seta; basal segment with small spine on lateral face.

Antennal peduncles overreaching distal margins of corneas by $0.2-0.5$ length of ultimate segments. Fifth and fourth segments each with few sparse tufts of setae. Third segment with tuft of setae at ventrodistal angle. Second segment with dorsolateral distal angle produced beyond proximal margin of fourth peduncular segment, terminating in small spine, partially concealed by stiff setae, mesial margin with several setae, dorsomesial distal angle with small spine Antennal acicles reaching to or nearly to bases of corneas, mesial margins setose. Antennal flagella with 1-3 long, and frequently also 1 or 2 short setae every article proximally, setae shorter and less numerous distally.

Maxillule with 1 apical bristle on internal endopodal lobe, external lobe well developed, not recurved. Third maxilliped with well developed crista dentata and 1 accessory tooth; merus and carpus unarmed. Sternite of third maxillipeds with pair of spinules on slightly produced median lobe.

Right cheliped (Figure 3b) larger, but not necessarily longer than left. Dactyl approximately as long as palm; dorsal surface with irregular longitudinal row of tubercles, partially obscured by thick, simple and pinnate setae, not usually extending to tip, remaining dorsal surface smooth; dorsomesial margin not distinctly delimited but rounded surface with 1 or 2 rows of tubercles or blunt small spines, partially to almost entirely concealed by thick, simple and pinnate setae; ventral surface with 2 or 3 rows of sparse short setae; cutting edge with 3 or 4 large calcareous teeth in proximal 0.8 , smaller calcareous teeth distally, terminating in small corneous claw. Palm slightly shorter than carpus; dorsomesial margin with irregular single or double row of tuberculate spines, dorsal surface unarmed or with scattered small spines and tubercles, partially hidden by sparse tufts of long pinnate setae; dorsolateral margin of palm and fixed finger with row of small or very small spines and sparse tufts of long pinnate setae; cutting edge of fixed finger with row of small, calcareous teeth, terminating in corneous claw; mesial face usually with few tubercles and sparse tufts of setae, lateral and ventral surfaces with scattered sparse tufts of setae. Carpus slightly shorter than merus; dorsodistal margin usually with moderately large spine, dorsomesial margin with row of small to moderately large spines and tufts of long pinnate setae, dorsal surface with few to several low tubercles or spinulose ridges, dorsolateral margin with row of small spines or spinulose ridges partially obscured by tufts of pinnate setae; lateral face with few scattered tufts of setae; mesial face (Figure 3c) with few sparse tufts of setae, ventromesial margin produced into winglike projection in both sexes, ventromesial margin unarmed; ventral surface with few tufts of setae. Merus subtriangular; dorsodistal margin with prominent spine and few tufts of setae; ventromesial margin with distal wing-like projection not particularly upturned, more distinctly developed in male, armed with few small spines in both sexes, ventromesial proximal angle with prominent tooth-like or spiniform projection; ventrolateral margin with row of spines or spinules distally and larger spine or tooth-like projection proximally. Ischium unarmed or with row of small tubercles on ventromesial margin.

Left cheliped (Figure 3d) appreciably slenderer than right. Dactyl longer than palm; dorsomesial margin with row small spines or tiny spinules and sparse setae not extending to tip, dorsal midline with few to row of small spines, surface with scattered tufts of pinnate setae; cutting edge with row of small calcareous teeth, and distally short row of corneous spines. Palm with row of spines on dorsomesial margin partially concealed by tufts of pinnate setae, dorsal surface of palm and fixed finger with scattered small spines or spinules and tufts of pinnate setae, dorsolateral margin of finger and palm with row of small spines; mesial, lateral and ventral surfaces with tufts of pinnate setae. Carpus with flattened dorsal surface, dorsomesial margin with row of moderately large spines, dorsodistal margin with few small spinules or tubercles, dorsal surface with scattered small 
spines, dorsolateral margin with row of small spines, all at least partially concealed by tufts of pinnate setae; mesial and lateral faces and ventral surface all with scattered tufts of pinnate setae. Merus with sparse tufts of pinnate setae on dorsal surface; ventromesial and ventrolateral margins each with row of small spines, most prominent laterally. Ischium with few small spines or minute tubercles on ventromesial margin.

Ambulatory legs (Figure 3e) similar; all segments with spare tufts of pinnate setae, particularly on dorsal and ventral surfaces. Dactyls $0.7-0.8$ length of propodi, ventral margins each with $4-8$ corneous spines. Propodi unarmed. Carpi each with dorsodistal spine. Meri and ischia unarmed. Fourth pereopods each with single row of scales in propodal rasp, at least partially concealed by tufts of setae; dactyls each with quite small terminal claw. Sternite of third pereopods with anterior lobe roundly subrectangular. Sternite of fifth pereopods with anterolateral distal angles somewhat produced.

Male with three unpaired unequally biramous pleopods; exopods well developed, endopods rudimentary. Female with four biramous pleopods, 2-4 with both rami well developed, 5 as in male; noneyed eggs with diameters approximately $0.5 \mathrm{~mm}$.

Telson (Figure $3 \mathrm{f}$ ) with deep lateral incisions; posterior lobes separated by moderately deep median cleft; terminal and lateral margins each with several well developed spines interspersed with slender, sometimes shorter spines.

\section{Colour}

In preservative, shield white with orange spots and patches particularly numerous anteriorly and laterally. Ocular peduncles each with 1 or 2 orange spots or patches dorsally in proximal half, tending to form band; ocular acicles each with 1 or 2 orange spots or blotches. Antennular peduncles each with 1 or 2 orange spots on penultimate segment dorsally. Antennal peduncles with 1 to several orange spots on each segment, spots ventrally on ultimate segment forming incomplete stripe on margin; antennal acicle with widely-spaced orange spots; antennal flagella each banded translucent and reddish brown. Chelipeds and ambulatory legs white with scattered orange spots and/or patches on each segment. Colouration of larger male similar, but spots are smaller and more numerous, giving more speckled than spotted appearance.

\section{Habitat}

Coarse to fine sand and rocks; algae; attached tunicates, gorgonians, sponges, free living corals.

\section{Distribution}

Known only from the Dampier Archipelago, Western Australia; 12-29 m.

\section{Etymology}

From the Greek stiktos, meaning spotted or speckled, and reflecting the spotted or speckled pattern of colouration remaining for several years in preservative.

\section{Variation}

As may be seen in the species' description, $P$. sticticus exhibits considerable morphological variation, some of which is clearly growth related. For example, the ocular peduncle become slender and increase in proportional length with increased animal size, whereas corneal diameter decreases. The number of corneous spines on the ventral margins of the ambulatory legs also increases with increased size. Whether the variations in armature of the chelipeds are also functions of growth or evidence of sexual dimorphism can not be determined at present. The single male is also the largest specimen.

\section{Affinities}

Pagurus sticticus is closely related to $P$. hedley $i$ and $P$. boriaustraliensis, two other Australian species of the anachoretus group of the genus as defined by McLaughlin and Forest (1999), and all three are present in the Dampier Archipelago. The median crest on the dorsal surface of the palm of each cheliped immediately distinguishes $P$. boriaustraliensis from the other two species, whereas the presence of a prominent ventromesial blunt spine or projection on the ventral surface of the merus of the right cheliped will separate the new species from $P$. hedleyi. Pagurus sticticus is also closely allied with the other two species of the group occurring in the Indo-Pacific, $P$. pitagsaleei McLaughlin, 2002b, and P. kulkarnii Sankolli, 1962, both of which share with the Australian species the characteristic wing-like development on the ventromesial surfaces of the merus and carpus of the right cheliped. McLaughlin (2002b) distinguished $P$. boriaustraliensis from $P$. pitagsaleei by the presence, in the former species, of a spinose ridge on the dorsal surface of each chela, but only two large setose protuberances in the latter as well as differences in the colouration between the two species. Pagurus kulkarnii and P. hedleyi are morphologically even more similar to one another than to the other three, but the armature of the dactyls of the chelae will serve to differentiate these two species. In P. kulkarmii the dorsal surfaces of the dactyls each has a covering of low tubercles, whereas the dactyls of $P$. hedlevi each has one or two rows of moderately large spines or spiniform tubercles.

Colouration will immediately separate all five species. The coloration has already been given above for $P$. hedleyi and $P$. sticticus. As noted by McLaughlin (2002b), the antennules of $P$. pitagsalee $i$ 
are greyish-white with short longitudinal stripes of reddish-black proximally, orange with blackish-red stripes distally; the palms of the chelae are mottled greyish-white and black. In contrast, the antennules of $P$. boriaustraliensis are cream-coloured and the palms of the chelae are cream-coloured with reddish-black or black stripes. Both species have stripes on the ambulatory legs with median and/or subdistal brown or reddish-brown bands superimposed. Colouration in $P$. kulkarnii is described as being generally light brown with longitudinal stripes of chocolate-brown on the major portions of the chelipeds and ambulatory legs (Sankolli, 1962), with the ocular peduncles orange proximally, brown distally, and the ocular acicles brown (Tirmizi and Siddiqui, 1982).

\section{Remarks}

Morgan's (1990) four small specimens of Pagurus $\mathrm{sp}$. were not available for reexamination; however, in being morphologically similar to $P$. boriaustraliensis and exhibiting a colour pattern of spots or speckles, $P$. sticticus n. sp. most probably is conspecific with Morgan's taxon from the Kimberley region.

In discussing species of the anachoretus group of Pagurus, Komai and Osawa (2001) and Komai and Rahayu (2004), called attention to the asymmetry of the fourth pereopods observed in several species of the group that they examined. Although size and setation dissimilarities between right and left fourth pereopods were not noted in the Dampier material, it cannot be assumed that these were not present in the three Dampier species as these asymmetries have been overlooked by most investigators. Rahayu and Komai (2000) and Komai and Osawa (2001), emphasized the existence of such asymmetry in $P$. pitagsaleei (as Pagurus sp. cf. boriaustraliensis) and presumed it to be the case for $P$. boriaustraliensis, but they also noted that there was interspecific variability. Three additional IndoPacific species of Pagurus assigned by Komai and Rahayu (2004) to the anachoretus group, $P$. decimbranchiae Komai and Osawa, 2001, $P$. moluccensis Haig and Ball, 1988, and $P$. fungiformis Komai and Rahayu, 2004, similarly exhibit these asymmetries in the fourth pereopods, but differ from the five previously discussed species in each having a two-spined ocular lobe and lacking the wing-like development of the merus and carpus of the right cheliped.

\section{ACKNOWLEDGEMENTS}

The author is particularly indebted to Diana Jones and Mrs. Melissa Titelius, Western Australian Museum, and to Dr. Gary Poore, Museum Victoria for making these collections available for study. This is a scientific contribution from the Shannon
Point Marine Center, Western Washington University.

\section{REFERENCES}

Alcock, A. (1905). Anomura. Fasc. I. Pagurides. Catalogue of the Indian Decapod Crustacea in the Collections of the Indian Museum 2: 1-197. Trustees of the Indian Museum, Calcutta

Berry, P.F. and Morgan, G.J. (1986). Part V. Decapod Crustacea of Scott and Seringapatam Reefs. Records of the Western Australian Museum Supplement 25: $59-62$.

Cook, S.D. (1989). Dardanus imbricatus (H. Milne Edwards) and descriptions of three new species of Dardanus (Decapoda, Anomura, Diogenidae). Memoirs of the Queensland Museum 27: 111-122.

Davie, P.J.F. (2002). Crustacea: Malacostraca: Eucarida (Part 2) Decapoda - Anomura, Brachyura. In Wells, A. and Houston ,W.W.K. (eds.) Zoological Catalogue of Australia. 19.3B. CSIRO Publishing, Melbourne, Australia. pp xiv +641 pp.

Fize, A. and Serène, R. (1955). Les Pagures du Vietnam. Institut Océanographique Nhatrang 45: 1-228.

Forest, J. (1995). Crustacea Decapoda Anomura: révision du genre Trizopagurus Forest, 1952 (Diogenidae), avec l'établissement de deux genres nouveaux. In Crosnier, A. (ed.), Résultalts des Campagnes MUSORSTOM, 13. Mémoires du Muséum National d'Histoire 163: 9-149.

Forest, J. and Morgan, G.J. (1991). A large new species of Dardanus (Crustacea, Decapoda, Diogenidae) from southwestern Australia. Bulletin du Muséum national d'Histoire naturelle Paris (4)13(A): 203-208.

Garcia-Gómez, J. (1994). The systematics of the genus Anapagurus Henderson, 1886, and a new genus for Anapagurus drachi Forest, 1966 (Crustacea, Decapoda, Paguridae). Zoologische Verhandelingen 295: $1-131$.

Haig, J. and Ball, E.E. (1988). Hermit crabs from northern Australian and eastern Indonesian waters (Crustacea Decapoda: Anomura: Paguroidea) collected during the 1975 Alpha Helix Expedition. Records of the Australian Museum 40: 151-196.

Henderson, J.R. (1888). Report on the Anomura collected by H.M.S. Challenger during the years 1873-76. Scientific Results of the Exploratory Voyage of HMS Challenger, (Zoology) 27: 1-221. Her Majesty's Stationary Office, Edinburgh etc.

Hewitt, M.A. (2004). Crustacea (excluding Cirripedia) of the Dampier Archipelago, Western Australia. In Jones, D.S. (ed.), Report on the results of the Western Australian Museum/Woodside Energy Ltd. Partnership to explore the Marine Biodiversity of the Dampier Archipelago Western Australia 1998-2002. Records of the Western Australian Museum, Supplement 66: 169-219.

Hutchins, J.B. and Berry, P.F. (2004). Station maps and lists for the diving expeditions (DA1 and DA3). In Jones, D.S. (ed.), Report on the results of the Western Australian Museum/Woodside Engergy Ltd. Partnership to explore the Marine Biodiversity of the 
Dampier Archipelago Western Australia 1998-2002. Records of the Western Australian Museum, Supplement 66: 7-14.

Jones, D.S. and Morgan, G.J. (1993). An annotated checklist of Crustacea from Rottnest Island, Western Australia. In Wells, F.E., Walker, D.I., Kirkman, 1 . and Lethbridge, R. (eds), Proceedings of the Fifth International Marine Biological Workshop: The Marine Flora and Fauna of Rottnest Island, Western Australia, Western Australian Museum, Perth 2: 135162.

Komai, T. and Osawa, M. (2001). A new distinctive species of pagurid hermit crab (Crustacea: Decapoda: Anomura) from Japan. Zoological Science 18: 12911301.

Komai, T. and Rahayu, D.L. ( 2004). Redescription of Pagurus moluccensis Haig and Ball, 1988, with description of a new species of Pagurus from Indonesia, and taxonomic notes on the Pagurus anachoretus group (Crustacea: Decapoda: Anomura: Paguridae). Raffles Bulletin of Zoology 52: 183-200.

Lewinsohn, Ch. (1969). Die Anomuren des Roten Meeres (Crustacea Decapoda: Paguridea, Galatheidea, Hippidea). Zoologische Verhandelingen 104: 1-213.

Martin, J.W. and Davis, G.E. (2001). An updated classification of the Recent Crustacea. Natural History Museum of Los Angeles County, Science Series 39: 1124.

McLaughlin, P.A. (1997). Crustacea Decapoda: Hermit crabs of the family Paguridae from the KARUBAR cruise in Indonesia. In Crosnier, A. and Bouchet, P. (eds), Résultats des Campagnes MUSORSTOM, 16. Mémoires du Muséum national d'Histoire naturelle 172: 433-572.

McLaughlin, P.A. (2002a). Diogenes pallescens Whitelegge, D. gardineri Alcock and D. serenei Forest (Decapoda; Anomura; Diogenidae): morphological variants or distinct species? Raffles Bulletin of Zoology 50: 81-94.

McLaughlin, P.A. (2002b). A review of the hermit crab (Decapoda: Anomura: Paguridea) fauna of southern Thailand, with particular emphasis on the Andaman Sea, and descriptions of three new species. pp. 385460. In Bruce, N., Berggman, M. and Bussawarit, S. (eds), Proceedings of the international workshop on the Crustacea in the Andaman Sea, Phuket Marine Biological Center 29 November - 20 December, 1998. Phuket Marine Biological Center Special Publication, Phuket Marine Biology Center, Phuket 23: 1-532.

McLaughlin, P.A. (2004). CRUSTACEA DECAPODA: A review of the hermit crab genus Nematopagurus $A$. Milne-Edwards \& Bouvier, 1892 and the descriptions of five new species. In Marshall, B. and Richer de Forges, B. (eds), Tropical Deep-Sea Benthos, 23. Mémoires du Muséum national d'Histoire naturelle 191: 151-229.

McLaughlin, P.A. (2005). The "jousseaumei group" of Diogenes (Decapoda: Paguroidea: Diogenidae) revisited. Journal of Crustacean Biology 25: 598-619.

Mclaughlin, P.A. (2006). Two new hermit crabs (Crustacea: Decapoda: Paguridae) from New Caledonia and environs. In Richer de Forges, B. and Justins, J.-L. (eds), Tropical Deep-Sea Benthos, 24.
Memoires du Muséum national d'Histoire naturelle 192: 335-347.

McLaughlin, P.A. (2007) Australian hermit crabs of the genera Paguristes Dana, Stratiotes Thomson, and Pseudopaguristes McLaughlin (Crustacea: Anomura: Paguroidea: Diogeneidae). In Jones D. S. (ed.), Report on the Crustacea collected during the Woodside Energy Ltd/Western Australian Museum Partnership to explore the Marine Biodiversity of the Dampier Archipelago, Western Australia, 1998-2002. Records of the Western Australian Museum Supplement 73: $185-271$.

McLaughlin, P.A. and Forest, J. (1999). Hermit crabs of the genus Pagurus Fabricius (Crustacea: Decapoda: Paguridae) from southeastern South Africa. Annals of the South Atrican Museum 105: 297-344.

McLaughlin, P.A. and Holthuis, L.B. (2000). In pursuit of J. F. W. Herbst's species of Diogenes (Anomura: Paguridea: Diogenidae). Journal of Crustacean Biology 21: 249-265.

McLaughlin, P.A. and Wang, Y.-L. (2002). The apparent rediscovery of Nematopagurus scutellichelis Alcock, 1905 (Decapoda: Anomura: Paguroidea: Paguridae) in the South China Sea, with notes on other regional species of the genus. Proceedings of the Biological Society of Washington 115: 741-753.

Milne Edwards, H. (1836). Observations zoologiques sur les Pagures et description d'un nouveau genre de la tribu des Paguriens. Annales des Sciences Naturelle Zoologie, Paris (2)6: 257-288.

Morgan, G.J. (1987a). A new and aberrant species of Paguristes (Anomura: Diogenidae) from northern Australia. Records of the Western Australian Museum 13: 379-386.

Morgan, G.J. (1987b). Hermit crabs (Decapoda, Anomura: Coenobitidae, Diogenidae, Paguridae) of Darwin and Port Essington, northern Australia. The Beagle, Records of the Northern Territory Museum of Arts and Sciences 4: 165-186.

Morgan, G.J. (1989). The hermit crabs (Decapoda: Anomura: Diogenidae, Paguridae) of southwestern Australia, with descriptions of two new species. Records of the Western Australian Museum 14: 391417.

Morgan, G.J. (1990). A collection of Thalassinidea, Anomura and Brachyura (Crustacea: Decapoda) from the Kimberley region of northwestern Australia. Zoologische Verhandelingen 265: 1-90.

Morgan, G.J. (1991). A review of the hermit crab genus Calcinus Dana (Crustacea: Decapoda: Diogenidae) from Australia, with descriptions of two new species. Invertebrate Taxonomy 5: 869-913.

Morgan, G.J. (1992). The hermit crabs (Crustacea: Decapoda: Coenobitidae, Diogenidae, Paguridae) of Christmas and Cocos (Keeling) Islands, Indian Ocean, with description of a new species of Paguristes. Raffles Bulletin of Zoology 40: 163-174

Powar, C.B. (1969). Musculature of the eyestalk in Crustacea. Acta Zoologica 50: 127-141.

Rahayu, D.L. (1996). Notes on littoral hermit crabs (excluding Coenobitidae) (Crustacea: Decapoda: Anomura) mainly from Singapore and peninsular Malaysia. Rattles Bulletin of Zoology 44: 335-355. 
Rahayu, D.L. (2005). Additions to the Indonesian fauna of the hermit crab genus Pseudopaguristes McLaughlin and a further division of the genus Paguristes Dana (Crustacea: Decapoda: Paguroidea: Diogenidae). Zootaxa 831: 1-42.

Rahayu, D.L. and Forest, J. (1993). Le genre Clibanarius (Crustacea, Decapoda, Diogenidae) en Indonésie, avec la description de six especces nouvelles. Bulletin du Muséum national d'Histoire naturelle, Paris [1992] (4) 14(A): 745-779.

Rahayu, D.L. and Komai, T. (2000). Shallow-water hermit crabs (Crustacea: Decapoda: Anomura: Diogenidae and Paguridae) of Phuket, Thailand. Phuket Marine Biological Center Research Bulletin 63: 21-40.

Sankolli, K.N. (1962). On a new species of hermit crab Pagurus kulkarnii sp. nov. (Anomura: Paguridae). Journal of the Zoological Society of India 13: 136-142.
Slack-Smith, S.M. (2004). Station map and list for the dredging expedition (DA2). In Jones, D.S. (ed.), Report on the results of the Western Australian Museum/Woodside Energy Ltd. Partnership to explore the Marine Biodiversity of the Dampier Archipelago Western Australia 1998-2002. Records of the Western Australian Museum, Supplement 66: 19-26.

Tirmizi, N.M. and Siddiqui, F.A. (1982). The marine fauna of Pakistan: 1 Hermit crabs (Crustacea, Anomura). 103 pp. University Grants Commission, Karachi.

Tudge, C.C. (1995). Hermit crabs of the Great Barrier Reef and coastal Queensland. 40 pp. Backhyus Publishers, Leiden.

Wang, F-Z. (1983). [List of Chinese hermit crabs] Donghai Marine Science 2: 50-57.

Whitelegge, T (1897). The fauna of Funafuti. The Crustacea. Memoirs of the Australian Museum 3: 7151. 